\title{
Silurian carcinosomatid eurypterids from the Prague Basin (Czech Republic)
}

\author{
PETR BUDIL, ŠTĚPÁN MANDA \& ODd ERIK TETLIE
}

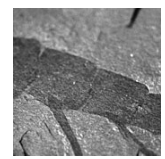

\begin{abstract}
The eurypterid record from the Prague Basin includes occasional Ludlow faunas, but in the uppermost Silurian (Přídolí) eurypterids suddenly become common in relatively deep water facies. Pterygotids clearly dominate these late Silurian faunas, whereas carcinosomatids are represented by the single species Eusarcana acrocephala, known from only a few specimens. This species is revised and its validity is discussed herein. A new eurypterid fauna found in deep water shale facies is described from the lower and middle part of the Motol Formation, Wenlock, Sheinwoodian-Homerian, Cyrtograptus murchisoni to C. lundgreni graptolite biozones, at Praha-Lochkov. It consists of common fragments of the carcinosomatid eurypterid described here as Eusarcana? sp. A and rare possible pterygotid fragments. This is the earliest evidence of carcinosomatids outside Laurentia and one of the earliest records of the group worldwide. This early occurrence outside a hypothetical Laurentian evolutionary centre is discussed with respect to the palaeobiogeography of other faunas colonising peri-Gondwanan basins after the decline of widespread early Silurian anoxia. A previous suggestion that carcinosomatids (presumed basal members of the Carcinosomatoidea) had similar distribution patterns to pterygotoids is discussed. Eurypterids migrated into the peri-Gondwanan realm from the tropical zone, but the dispersion potential of carcinosomatids into the temperate and cool water realm was probably lower than that of pterygotids. In the Prague Basin, the carcinosomatid-dominated fauna of the Wenlock age was replaced in the late Silurian by a pterygotid-dominated fauna. - Key words: Eurypterida, Carcinosomatidae, Prague Basin, Wenlock, Přídolí.
\end{abstract}

Budil, P., MANDA, Š. \& TETLIE, O.E. 2014. Silurian carcinosomatid eurypterids from the Prague Basin (Czech Republic). Bulletin of Geosciences 89(2), 257-267 (7 figures). Czech Geological Survey, Prague. ISSN 1214-1119. Manuscript received April 19, 2013; accepted in revised form January 6, 2014; published online March 11, 2014; issued May 19, 2014.

Petr Budil \& Štěpán Manda, Czech Geological Survey, Klárov 3, 11821 Praha 1, Czech Republic; petr.budil@geology.cz, stepan.manda@geology.cz•Odd Erik Tetlie, Horka, N-7863Overhalla,Norway; mixopterus@yahoo.co.uk

Eurypterids form a prominent component of Silurian faunas in the peri-Gondwanan Prague Basin and, together with cephalopods, are the largest known animals of the Silurian (Lamsdell \& Braddy 2010). The oldest eurypterids previously described from the Prague Basin originate from the Ludlow cephalopod limestones, and the acme of the group starts in the lowermost Prídolí but they remain common until the upper Lochkovian. Published data (e.g. Prantl \& Přibyl 1948) clearly demonstrate that pterygotids are dominant in the Prague Basin whereas carcinosomatids are very rare. Pterygotids have also been recorded from other peri-Gondwanan basins such as Catalonia, Iberia (Chlupáč et al. 1997) and Sardinia (Gnoli 1992, Corradini et al. 2009). Increasing abundance of eurypterids throughout the Silurian is a feature shared between the periGondwanan and perhaps even the global marine faunas (Lamsdell \& Braddy 2010).

The Czech representatives of the Family Carcinosomatidae Størmer, 1934 are poorly known compared to the well-documented Pterygotoidea Clarke \& Ruedemann,
1912, which were thoroughly revised by Chlupáč (1994). Following the pioneering work of Barrande (1872) on pterygotids, the first descriptions of carcinosomatids from the Barrandian area were published by Semper (1898) and Seemann (1906). Some of these carcinosomatid specimens were also figured and prepared for formal description by O.P. Novák (MS), who unfortunately died (1892) before his post-Barrande volume of the Système silurien du centre de la Bohême was finished. The most recent description of carcinosomatid remains from the Barrandian area was published more than sixty years ago by Prantl \& Přribyl (1948).

The new discovery of carcinosomatids in the Sheinwoodian and lower Homerian (Wenlock) of the Prague Basin, described in this paper, are important for our understanding of the evolution and dispersal of the group during the Silurian. It is apparent that the Silurian faunal associations of Perunica were influenced by the occasional influx of taxa with Laurentian affinities, especially during important faunal exchange events (see also Budil et al. 2010). 

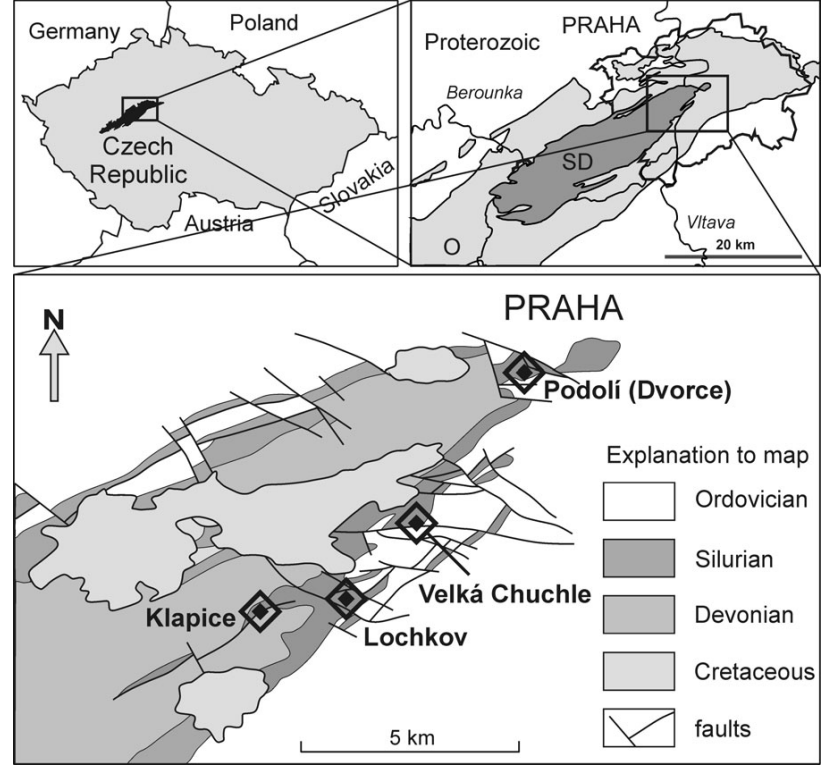

Figure 1. Maps showing the location of the Prague Basin in the Czech Republic, the distribution of Palaeozoic rocks in Central Bohemia, and detail of the NE part of the Prague Basin with localities yielding carcinosomatids. O - Ordovician, SD - Silurian and Devonian.

\section{Systematic palaeontology}

The specimens studied are deposited in the Czech Geological Survey, collection of Petr Budil (CGS PB), the National Museum, Prague (NM L), and the Department of Geodynamics and Sedimentology, Universität Wien (UW).

Order Eurypterida Burmeister, 1843

Suborder Eurypterina Burmeister, 1843

Superfamily Carcinosomatoidea Størmer, 1934

Remarks. - During the review process, the handling editor kindly drew our attention to the fact that, in accordance with the Principle of Coordination (ICZN 1999, Article 36.1) Carcinosomatoidea has priority over Mixopteroidea Caster \& Kjellesvig-Waering in Størmer, 1955 as the name of the superfamily, though the latter name was used by some recent authors.

Family Carcinosomatidae Størmer, 1934

\section{Genus Eusarcana Strand, 1942}

1875 Eusarcus; Grote \& Pitt, p. 1 [preoccupied by Eusarcus Perty, 1833 (Opiliones)].

1942 Eusarcana; Strand, p. 387 [replacement name].

1964 Paracarcinosoma; Caster \& Kjellesvig-Waering, p. 312 [fide Dunlop \& Lamsdell 2012].

2012 Eusarcana Strand, 1942. - Dunlop \& Lamsdell, pp. 19-22.

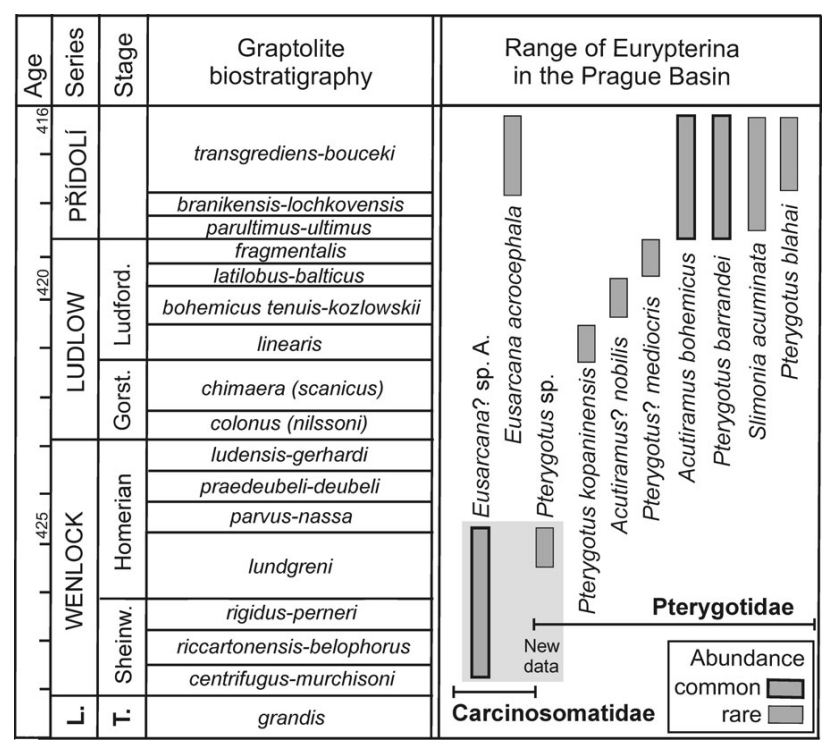

Figure 2. Stratigraphical distribution of eurypterids in the Silurian of the Prague Basin. Ranges of late Silurian eurypterids after Chlupáč in Kř́ž et al. (1986) and Chlupáč (1994). Graptolites zones after Štorch (1994, 1995), Manda \& Kříž (2006) and Manda et al. (2012).

Type species. - Eusarcus scorpionis Grote \& Pitt, 1875, Přídolí, Williamsville Formation of New York State, USA, and Ontario, Canada.

Other included species. - E. acrocephala (Semper, 1898), Přídolí of the Prague Basin, Bohemia, Czech Republic; E. obesa (Woodward, 1868), Wenlock-Ludlow of Lesmahagow, South Lanarkshire, Scotland, United Kingdom; E.? sp. A, Wenlock of the Prague Basin, Bohemia, Czech Republic.

Diagnosis. - Carcinosomatidae with relatively weakly developed spinosity on appendages II-V and a curved telson (emended from Tetlie 2004).

\section{Eusarcana acrocephala (Semper, 1898)}

Figures 3, 4

1898 Eurypterus acrocephalus sp. nov.; Semper, pp. 85-87, pl. 13 (2).

1906 Eurypterus punctatus Woodward et acrocephalus Semper. - Seemann, p. 55, pl. 4, fig. 7.

1948 Carcinosoma scorpionis (Grote \& Pitt, 1875). Prantl \& Přibyl, pp. 99-102, pl. 7, figs 5, 6; pl. 8, figs $1,2$.

2012 Eusarcana acrocephala (Semper, 1898). - Dunlop \& Lamsdell, p. 21.

Diagnosis. - Eusarcana with strongly recurved lateral carapace sides; metastoma apparently oval; mesosoma very 

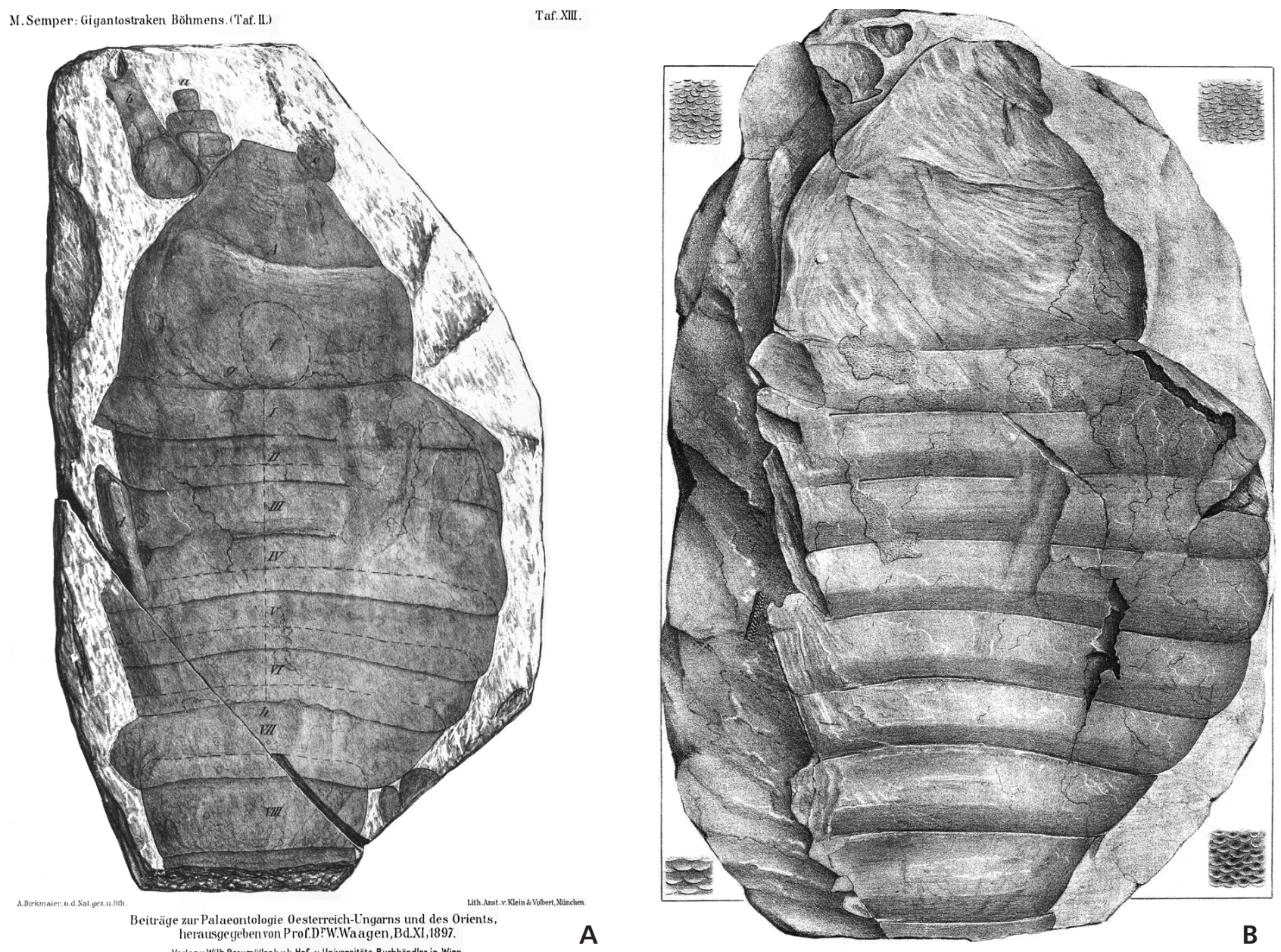

Figure 3. Eusarcana acrocephala (Semper, 1898). A - illustration of the holotype UW 1906/V/2 by Semper [1898, pl. 8 (2)]. B - illustration of the holotype counterpart NM L 96 by Novák (MS); note the left-right inversion of the illustration.

wide; first segment of metasoma wide and short for the genus; first order opisthosomal differentiation almost absent.

Holotype. - UW 1906/V/2, figured by Semper [1898, pl. 13 (2)], Figs 3A and 4E herein; Přídolí, Požáry Formation, Praha-Dvorce (= Podolí). Compared to the 1898 figure, the left posterior portion of the part with the abdomen is now broken off and missing - it may have been lost during bombing of the University collections towards the end of the Second World War. The counterpart of the specimen, figured by Novák (MS) and Prantl \& Přibyl (1948, pl. 8, fig. 1; as Carcinosoma scorpionis) and in Figs 3B and 4F herein, is stored in the National Museum Prague, as NM L 96.

Other material. - NM L 30372, incomplete carapace with remains of prosomal appendages and mesosoma, Požáry Formation, Kosoř; NM L 26, 55, isolated prosomal appendages, Požáry Formation, Praha-Dvorce (= Podolí), quarry of former cement works. Prantl \& Prribyl (1948, pl. 6, figs 5, 6, p. 49) figured and discussed also remains of walk- ing legs and telson from the Požáry Formation, Praha-Velká Chuchle. They also discussed (p. 49) the occurrence of the species in the Lower Devonian Lochkov Formation at Kosoř, but this material has not been found in the collections of the National Museum, Prague.

Description. - See Prantl \& Přibyl (1948, pp. 99-102).

Discussion. - Prantl \& Prribyl (1948) pointed out the "relatively well preserved imprint of the dorsal side of the body" - the prosoma (including incomplete appendages), nearly complete mesosoma and three segments of the metasoma - in NM L 96, which they assigned to Carcinosoma scorpionis (Grote \& Pitt, 1875). Prantl \& Přibyl also recognized that this specimen is the counterpart to the original of Semper (1898). Both part and counterpart thus represent the holotype by monotypy, although stored in two different institutions. Semper's original specimen was considered lost, but was discovered in the collections of the Department of Geodynamics and Sedimentology, Universität 
Wien, in late 2012 by F. Popp. Together with its unique shape, a label attached directly to the specimen enables its unequivocal identification as the holotype. J.J. Jahn, not Semper, donated the specimen to the collections in 1906, but the species epithet acrocephalus is not mentioned in the acquisition list, although other type specimens of the same acquisition (e.g. Pterygotus blahai Semper, 1898) are correctly listed. The holotype was found in the former "Dvorce" quarry in about 1880 (on a label attached to the counterpart, NM L 96, the year 1882 is mentioned, together with the name Shück or Shüek, probably the person who donated the specimen, see Fig. 4F). The paper of Semper (1898) was discussed shortly afterwards by Perner (1898) who mentioned "comparatively better material stored in the Czech Museum, deposited in the Barrande and Novák collections". However, the first person to illustrate the holotype counterpart was Novák (MS) (see Fig. 3B; illustration kindly provided to us in 2009 by V. Turek). Prantl \& Přibyl (1948, pl. 8, fig. 1) also illustrated the counterpart, correctly pointing out that it comes from the Novák collection and stating that Semper's original specimen was unavailable to them. Both part and counterpart of the holotype are re-figured together here for the first time (Fig. 4C, E, F).

Although Prantl \& Přibyl (1948) considered the five specimens of Eurypterus acrocephalus from diverse localities in the Prague Basin to be conspecific with Eusarcana scorpionis, Caster \& Kjellesvig-Waering (1964) considered the former to be a valid species. Tetlie (2007) and Dunlop \& Lamsdell (2012) supported this conclusion, with which we also agree. The differences between the species, in the shape of carapace, shape of metastoma, shape of mesosoma, shape of the first metasomal segment and first order opisthosomal differentiation, justify the validity of Eusarcana acrocephala. The two species are probably closely related, although in some respects E. acrocephala is more similar to, for instance, Carcinosoma newlini Claypole, 1890 than it is to E. scorpionis. The typical crescent-like exoskeletal sculpture of E. acrocephala is also unlike that of E. scorpionis (for further discussion, see Semper 1898, p. 16 and the reconstruction of Novák, MS, in Fig. 3B herein). The considerable palaeogeographic distance between the respective type areas also suggests the existence of separate geographic species.
Prantl \& Přribyl (1948) based their detailed description and discussion of the Bohemian specimens mainly on the holotype counterpart, NM L 96, and this description is for the most part still valid.

Occurrence. - Požáry Formation, Přídolí, M. bouceki-M. transgrediens graptolite biozone. Prague Basin (Bohemia, Czech Republic).

\section{Eusarcana? sp. A}

Figures 5, 6A?, D?-L?, M-Q

Material. - The best preserved specimen, CGS PB 1043 (Figs 5, 6M-Q), is an articulated, incomplete, probably third or fourth prosomal appendage, from the Motol Formation (deeper-water facies development, graptolite shale facies), Wenlock, Sheinwoodian, Cyrtograptus murchisoni graptolite biozone, in tunnel excavations for a highway at PrahaLochkov. Thirteen other exoskeletal fragments are known, CGS PB 1034-1037, 1039-1042 and 1044-1048, from the Wenlock, Sheinwoodian-early Homerian, Cyrtograptus perneri-C. lundgreni graptolite biozones, at the same locality, but their identification is speculative.

Description. - Prosomal appendage (probably third or fourth) of carcinosomatid type (see Tollerton 1989), with long hook-like distal spine. Podomere 8 of elongate rectangular outline, protruding into a long spine. Podomere 7 short, of rectangular outline, protruding into two long but narrow spines. Podomeres 6-3 of subrectangular outline. Podomere 2 incompletely preserved.

Together with the appendage, fragmentary remains of other body parts are known, mostly coming from younger horizons (Sheinwoodian and Homerian, Cyrtograptus perneri-C. lundgreni graptolite biozones) at the same locality. Specimen CGS PB 1040 (Fig. 6L) probably represents four articulated but poorly preserved segments of the mesosoma. The identification of the other specimens is very speculative but they clearly represent eurypterids and/or the remains of other weakly mineralised, mediumsized arthropods (the eurypterid interpretation is the most parsimonious). Specimen CGS PB 1042 (Fig. 6A) may be

Figure 4. Eusarcana acrocephala (Semper, 1898). • A - prosomal appendage (endognath), NM L 55, figured by Seemann (1906, pl. 4, fig. 7) as Eurypterus punctatus Woodward et acrocephalus Semper. Praha-Dvorce, quarry of former cement works. Požáry Formation (originally designated as $\left.\mathrm{E}_{1} ß\right)$. $・ \mathrm{~B}$ - distal portion of swimming appendage, NM L 26, figured by Prantl \& Přibyl (1948, pl. 6, fig. 2) as Carcinosoma scorpionis (Grote \& Pitt). Praha-Dvorce, quarry of former cement works (Prantl \& Přibyl 1948 gave the locality incorrectly as Kosoř). Požáry Formation (originally designated as $\left.\mathrm{E} \beta_{2}\right)$. $・ \mathrm{C}, \mathrm{E}$ - holotype UW 1906/V/2, incomplete specimen, figured by Semper (1898, pl. 8, fig. 2). Praha-Dvorce, quarry of former cement works. Přídolí, Požáry Formation (originally designated as Ober-Silur $\mathrm{e}_{1}$ ). A - detail of remnants of the prosomal appendages; B - dorsal side of exoskeleton. - D - ventral side of incomplete prosoma and mesosoma showing part of prosomal appendages, NM L 30372, figured by Prantl \& Přibyl (1948, pl. 8, fig. 2) as Carcinosoma scorpionis (Grote \& Pitt). Kosoř. Požáry Formation. • F - counterpart of the holotype NM L 96, figured by Prantl \& Přibyl (1948, pl. 8, fig. 1) as Carcinosoma scorpionis (Grote \& Pitt); coll. O.P. Novák. Praha-Dvorce, quarry of former cement works. Př́idolí, Požáry Formation, Monograptus bouceki graptolite zone (originally designated as $\mathrm{E}_{2}$ ). Scale bars represent $10 \mathrm{~mm}$. 
Petr Budil et al. • Silurian carcinosomatid eurypterids from the Prague Basin

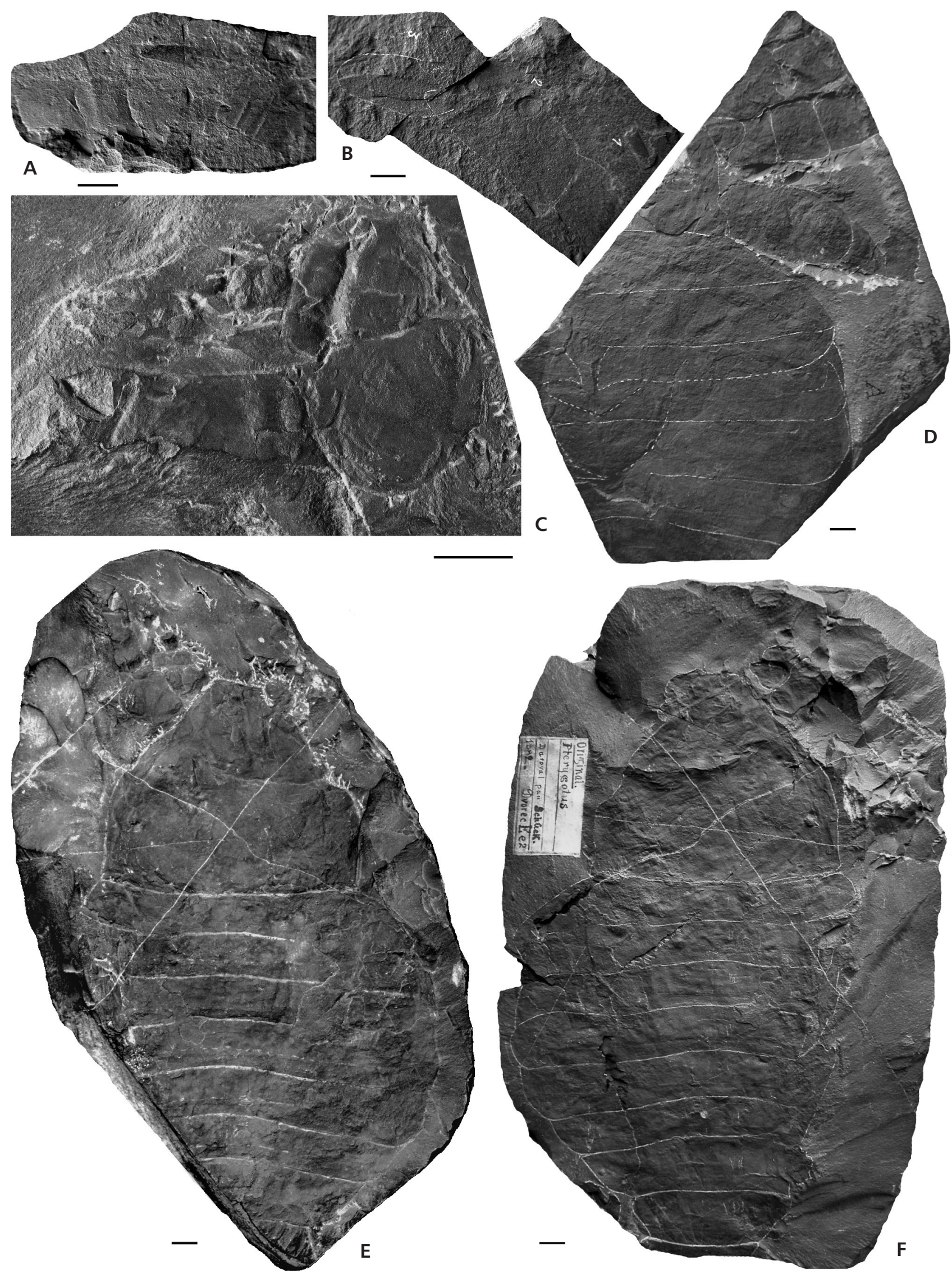




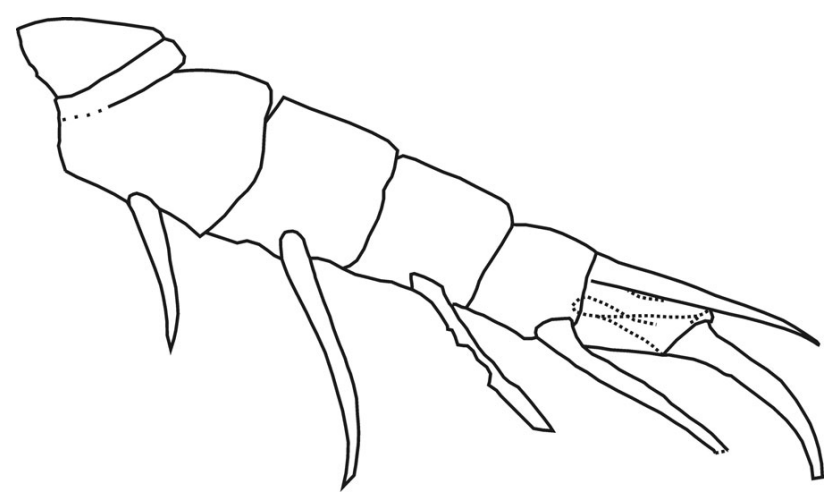

Figure 5. Eusarcana? sp. Interpretive drawing of specimen CGS PB 1043, a probable third or fourth prosomal appendage.

the remains of a carapace. CGS PB 1039 and 1045 (Fig. 6D, J respectively) may represent the distal segment of the swimming appendage. CGS PB 1041, 1047 and 1044 (Fig. 6G-I) may be fragments of mesosomal segments. CGS PB 1034 (Fig. 6F) may represent the remains of a telson. A large exoskeletal fragment CGS PB 1037 (Fig. 6E, K) may represent the remains of a large metasomal segment.

Discussion. - Only one well-preserved, articulated third or fourth prosomal appendage with seven distalmost podomeres is known, together with several poorly determinable remains, which makes the generic identification of the new material impossible. The appendage is clearly of carcinosomatid type, with long, slender spines much like those in Eusarcana scorpionis and Carcinosoma newlini, and unlike the broad, flattened spines in Carcinosoma? punctatum (Woodward, 1868) (see also Kjellesvig-Waering 1961). According to Caster \& Kjellesvig-Waering (1964), this gracile morphology is more consistent with Eusarcana than Carcinosoma; in the latter genus the prosomal appendages are generally more robust with better-developed spinosity (Kjellesvig-Waering 1958). Since the occurrence of Eusarcana is confirmed in the Prague Basin in the Přídolí (based on E. acrocephala), it is most parsimonious to suggest that this new material may belong to the same genus. Compared to the much younger type species E. scorpionis from the Přídolí, the present material differs especially in the longer and more slender spines on the appendage. E. obesa (Woodward, 1868), which is possibly contemporaneous with $E$.? sp. A, differs from it in the shorter and weaker spinosity of the prosomal appendages. Comparison with the poorly preserved prosomal appendages of the late Silurian (Přídolí) E. acrocephala is difficult but they also seem to be more robust ( $c f$. Fig. 6A, D-Q and Prantl \& Přibyl 1948, pl. 7, fig. 5 - this specimen cannot be found in the collections of the National Museum, Prague).

Occurrence. - We have studied only material from Wenlock rocks exposed in the Lochkov Tunnel digging. During excavation of the tunnel several other fragments of eurypterids were found but were not collected due to their poor preservation. Consequently, current knowledge of eurypterid distribution in the Silurian of Bohemia is most probably affected by sampling bias and preservation. The single well-preserved specimen of Eusarcana? sp. A was found at the boundary between shales and a limestone bed with common Phragmoceras (Manda 2007) - extremely rare in the shale-dominant facies of the Motol Formation. Similarly, the younger Př́idolí specimens of Eusarcana are usually preserved in platy limestone with intercalations of calcareous shales.

\section{Discussion and conclusions}

Carcinosomatoids from Silurian strata of the Prague Basin are of significance in relation to: 1) the composition and dynamics of Silurian faunas; and 2) palaeobiogeographical patterns and the reconstruction of ancient migration routes.

\section{Distribution pattern of eurypterids in the Silurian rocks of the Prague Basin}

Eurypterids have previously been known only from the upper Silurian and Lower Devonian of the Prague Basin, with rare remains from the Ludlow cephalopod limestones (Chlupáč 1994) and abundant specimens from shales and

Figure 6. A, D-Q - Eusarcana? sp. A, Silurian, Motol Formation, Praha-Lochkov, highway tunnel excavation. All except M-Q from Homerian, C. lundgreni graptolite biozone. $\bullet$ A - indeterminable fragment of exoskeleton, possibly part of prosoma, CGS PB 1042 . $\bullet$ D - indeterminable fragment of exoskeleton (?segment of walking appendage), CGS PB 1039. • E - indeterminable large fragment of exoskeleton, CGS PB 1037b. $\bullet$ F - indeterminable fragment of exoskeleton (?telson), CGS PB 1034. • G, H - indeterminable fragments of exoskeleton. G - CGS PB 1041; H - CGS PB 1047. • I - indeterminable fragment of exoskeleton, possibly two articulated mesosomal segments, CGS PB 1044. $\bullet \mathrm{J}-$ indeterminable fragment of exoskeleton (?swimming appendage), CGS PB 1045. • K - indeterminable larger fragment of exoskeleton (?part of mesosoma), CGS PB 1037b. • L - possible articulated metasoma with indeterminable fragment of exoskeleton, CGS PB 1040a. $\bullet$ M-Q - possibly $3^{\text {rd }}$ or $4^{\text {th }}$ prosomal appendage, CGS PB 1043 , Sheinwoodian, Cyrtograptus murchisoni graptolite biozone; $\mathrm{M}$ - dorsal view; $\mathrm{N}$ - dorsal view in right-side lateral illumination; $\mathrm{O}$ - dorsal view in right-side illumination; P - dorsolateral view; Q - dorsolateral view in different illumination. $\bullet \mathrm{B}, \mathrm{C}-$ Pterygotus sp., Silurian, Motol Formation, Praha-Lochkov, highway tunnel excavation, C. lundgreni graptolite biozone, fragment of questionable telson, CGS PB 1038; B - negative counterpart; C-positive part. Scale bars represent $10 \mathrm{~mm}$. 
Petr Budil et al. • Silurian carcinosomatid eurypterids from the Prague Basin
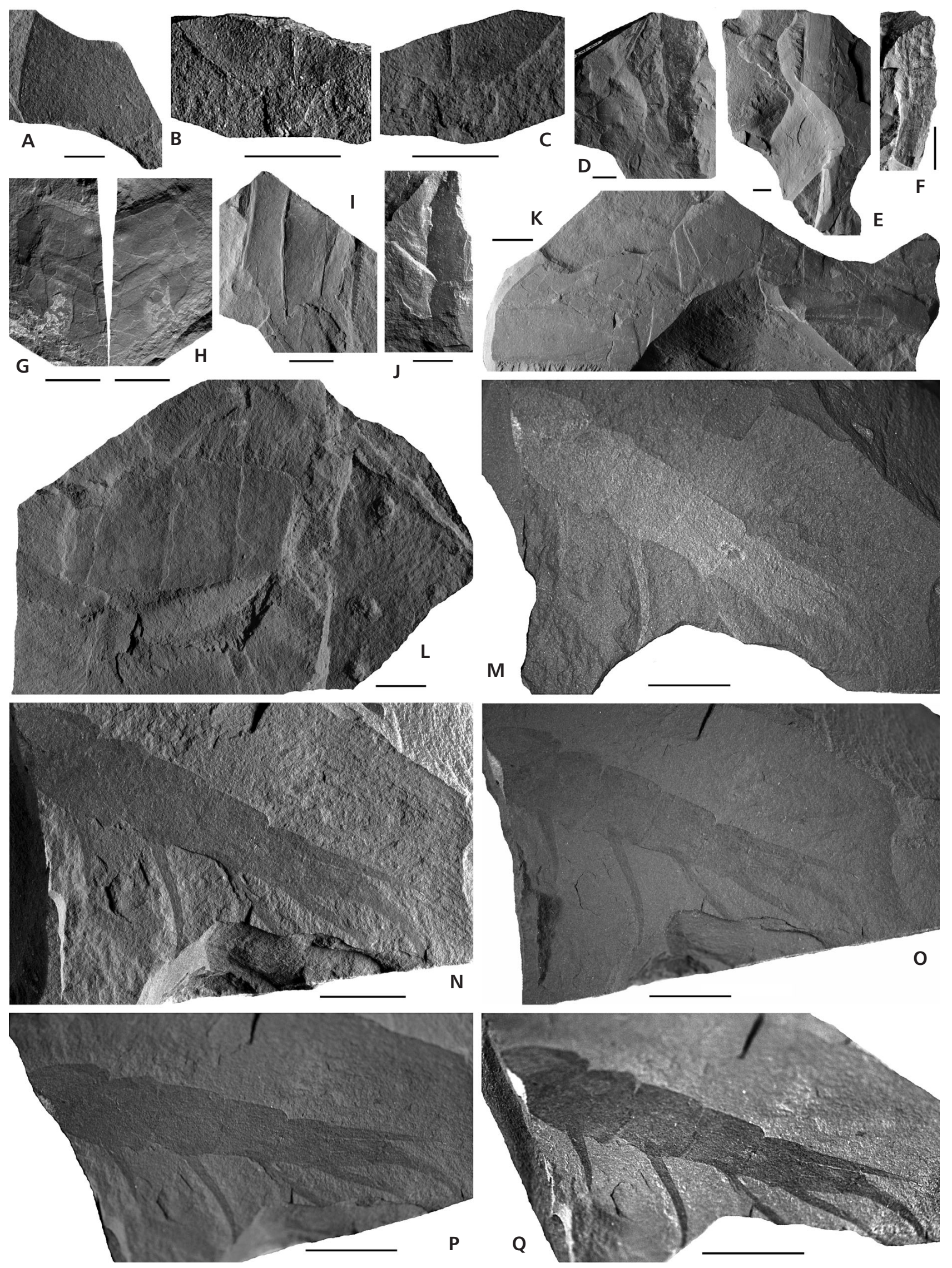


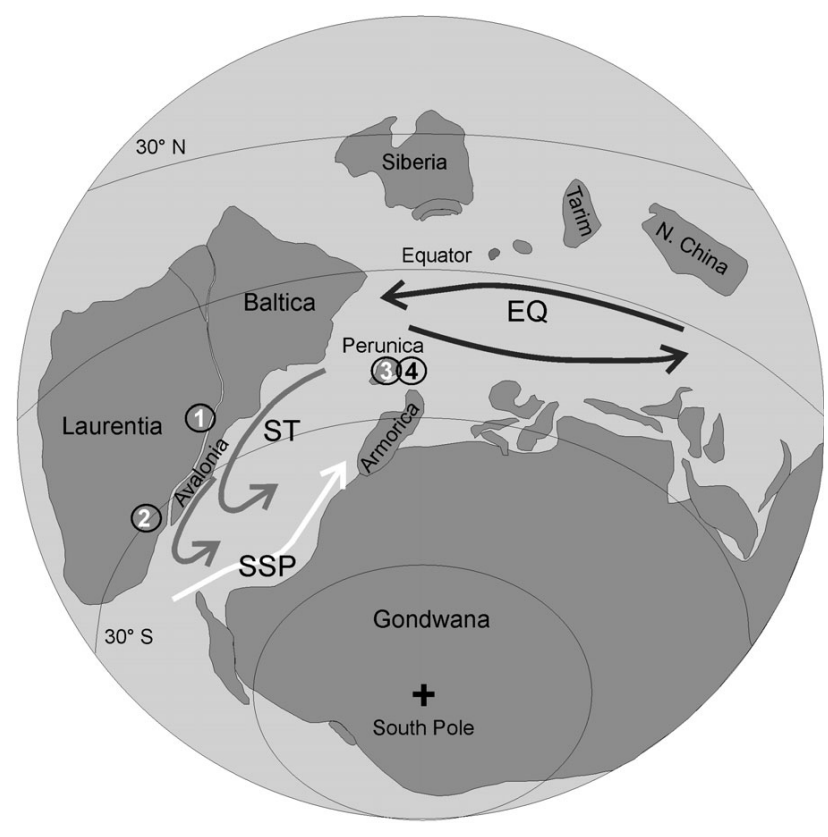

Figure 7. Global palaeogeographic reconstruction for the Wenlock and Ludlow (modified from Cocks \& Torsvik 2002, 2006, supplemented by data of Scotese \& McKerrow 1990, Wilde et al. 1991, Krs et al. 2001, Stampfli et al. 2002, Křǐž et al. 2003; position of Perunica slightly modified after Fatka \& Mergl 2009). Circles numbered 1-4 show occurrences of Eusarcana as follows: 1 - Lesmahagow, South Lanarkshire, Scotland, UK [E. obesa, Wenlock to Ludlow; according to Lamsdell \& Selden 2013, this species is probably based on a juvenile of Carcinosoma scorpioides (Woodward, 1868)]; 2 - Buffalo Waterlime, New York State, USA (E. scorpionis, Ludlow); 3 - Motol Formation, Prague Basin. (E.? sp. A, Wenlock); 4 - Požáry Formation, Prague Basin (Eusarcana acrocephala, Přídolí). Abbreviations: EQ - Equatorial Current; ST - South Tropical Current; SSP - South Subpolar Current. See discussion in the text.

platy limestones of Přídolí age in which they represent, together with phyllocarids and cephalopods, the most common nectobenthic animals. Pterygotids are most common whereas carcinosomatids are extremely rare (Prantl \& Přibyl 1948, Chlupáč in Kř́iž et al. 1986). The newly collected, common specimens of carcinosomatids from off-shore shale facies of the Motol Formation at the Lochkov tunnel excavation expand our knowledge of Silurian communities of the Prague Basin. The Wenlock carcinosomatids inhabited a very similar environment to the Přídolí pterygotids, but our understanding of eurypterid distribution in the Prague Basin may be affected by sampling bias due to the poor preservation.

Our study supports the suggestion of Tetlie (2007) that the carcinosomatids (basal members of the Carcinosomatoidea) had a similar distribution to that of the pterygotoids. In the Prague Basin carcinosomatids and pterygotids both occur in deep water facies of the Wenlock but carcinosomatids are more abundant. Only one very poorly preserved specimen, CGS PB 1038, a possible telson with characteristic keel-like medial elevation, from the Lochkov highway tunnel excavations (Motol Formation, Sheinwoodian, Cyrtograptus murchisoni graptolite Biozone) can be attributed with some confidence to a pterygotid (Fig. 6B, C). By contrast, in late Silurian strata pterygotids are dominant whereas carcinosomatids are very rare.

\section{Palaeobiogeographical significance of carcinosomatoids and their migration pattern}

Tetlie (2007) suggested that carcinosomatoids probably originated in Laurentia. The more primitive forms were able swimmers and some forms were able to spread throughout most of the world. Some of the genera (e.g. the stem forms of the carcinosomatoid clade) have been interpreted as fully marine (Kjellesvig-Waering 1961), as opposed to more advanced forms with near-shore brackish or hypersaline occurrences. The majority of carcinosomatoid taxa are known from Laurentia, Baltica and Avalonia. Lamsdell et al. (2013), on the other hand, tentatively suggested a Gondwanan origination for eurypterids.

The first known representative of Eusarcana is E. obesa from the Wenlock of Lesmahagow, Scotland, although according to Lamsdell \& Selden (2013) the specimen on which this species was based is most likely a juvenile Carcinosoma scorpioides (Woodward, 1868). The new discoveries of possible Eusarcana in the Prague Basin are thus among the earliest known occurrences of the genus worldwide. Isolated records from the upper Silurian(?) of Vietnam (Braddy et al. 2002) and Bohemia (e.g. Prantl \& Přibyl 1948) also show that the terranes of Annamia and Perunica were within the migration range of these eurypterids at this time (Tetlie 2007). It is apparent, however, that Perunica was accessible for these animals at the latest in the Wenlock. Annamia is considered to have been drifting north of the equator (east of Laurussia and north of Gondwana) at that time, while Perunica was south and west of Laurussia (Tetlie 2007; Torsvik \& Cocks 2004; Cocks \& Torsvik 2002, 2006). In any case, carcinosomatid immigrants into the Prague Basin would have had to cross a significant portion of the Rheic Ocean, probably including its deeper parts (Fig. 7).

Carcinosomatids appeared in the Prague Basin in the early Wenlock, as early Silurian anoxic conditions declined due to the activation of sea currents. Other immigrants of Laurentian and/or Baltic-Avalonian origin also appeared in the Prague Basin in the Silurian, including brachiopods (Havlíček \& Štorch 1990), nautiloids (Manda 2007, 2008), bivalves (Kříž 2008) and bryozoans (Ernst et al. 2011). The early to late Wenlock carcinosomatids newly documented herein (the youngest specimens from the Cyrtograptus lundgreni Biozone) formed part of a pioneer community (Havlíček \& Štorch 1990) that inhabited deeper water conditions in which graptolites were dominant. 
Although the Prague Basin was colonised mainly with immigrants from Baltica and Avalonia, there are also some immigrants of Laurentian origin. Laurentian faunas were rather similar to those of Baltica and Avalonia but also included some endemic groups that originated before the collision of all these continents in the latest Silurian. The migration of carcinosomatids into the Prague Basin was very soon followed by the Laurentian phyllocarid crustacean Ceratiocaris papilio Salter, 1859 (in Murchison 1859) in the lower Ludfordian (see Budil et al. 2010). Tetlie (2007) suggested that the carcinosomatids had a similar distribution to the pterygotids (see above), but carcinosomatids appeared earlier in the Prague Basin (middle Wenlock) than pterygotids (late Wenlock-Ludlow).

Although eurypterids of Bohemian affinity were present in other peri-Gondwanan terranes in the late Silurian and early Devonian (e.g. Sardinia and northern Spain, see Gnoli 1992, Chlupáč et al. 1997, Corradini et al. 2009), the only known occurrence of carcinosomatids in European peri-Gondwana is in the Prague Basin. This occurrence is consistent with the dispersion pattern of many other invertebrate groups; e.g. nautiloid cephalopods (Gnoli 2003; Manda 2008; Manda \& Frýda 2010; Turek \& Manda 2011, 2012; Histon 2012a, b), shallow-water bivalve communities (Kříž 2008, Cope \& Kříž 2013) and inarticulate brachiopods (Mergl 2006, 2010). We suggest that carcinosomatids had a more nektic lifestyle whereas pterygotids were more demersal, possibly explaining the replacement of a carcinosomatid fauna in the Wenlock by a pterygotid fauna in the Ludlow and Př́dolí. If carcinosomatids were predominantly nektic, their migration potential would have been higher than for the pterygotids, and they may have been the earliest immigrants. Their later replacement by pterygotids reflected their lower tolerance to changing environments. A similar pattern has been documented in cephalopods (Manda 2008): earlier immigrants were actively swimming forms that were less tolerant of environmental change, and these were later replaced by demersal cephalopods that were tolerant of change.

\section{Acknowledgements}

We wish to express many thanks to David Holloway, Jason Dunlop and an anonymous reviewer for their valuable comments which substantially improved the quality of the manuscript; and to V. Turek and M. Valent, Palaeontological Department of the National Museum, Prague, and F. Popp, Department of Geodynamics and Sedimentology, Universität Wien, for their enthusiastic help in searching for the specimens of Semper (1898) and Seemann (1906). V. Turek also helped us greatly in providing Novák's (MS) unpublished figure of Eusacarna acrocephala. P. Budil junior is acknowledged for help with graphics. The Grant Agency of the Czech Republic (Project No. P210/14/16124S) and the internal project of the CGS No. 334600 are acknowledged for financial support.

\section{References}

BARRANDE, J. 1872. Systême silurien du centre de la Bohême. lère partie: Recherches paléontologique. Supplément au Vol. 1. Trilobites, crustacés divers et poissons. 647 pp. Published by the author, Prague \& Paris.

Braddy, S.J., Selden, P.A. \& Truong, D.N. 2002. A new carcinosomatid eurypterid from the upper Silurian of northern Vietnam. Palaeontology 45, 897-915.

DOI 10.1111/1475-4983.00267

Budil, P., Collette, J. \& Manda, Š. 2010. An unusual occurrence of the Laurentian phyllocarid crustacean Ceratiocaris papilio Salter in the lower Ludfordian (Silurian) of Bohemia (peri-Gondwana). Bulletin of Geosciences 85, 551-564. DOI 10.3140/bull.geosci.1212

Burmeister, H. 1843. Die Organisation der Trilobiten, aus ihren lebenden Verwandten entwickelt; nebst einer systematischen Uebersicht aller zeither beschriebenen Arten. 148 pp. Reimer, Berlin. DOI 10.5962/bhl.title.9086

Caster, K.E. \& KJellesvig-Waering, E.N. 1964. Upper Ordovician eurypterids from Ohio. Palaeontographica Americana 4, 300-358.

Chlupáč, I. 1994. Pterygotid eurypterids (Arthropoda, Chelicerata) in the Silurian and Devonian of Bohemia. Journal of the Czech Geological Society 39, 147-162.

CHLupÁč, I. 1999. Some problematical arthropods from the Upper Ordovician Letná Formation of Bohemia. Journal of the Czech Geological Society 44, 79-90.

Chlupáč, I., Ferrer, E., Magrans, J., Mane, R. \& Sanz, J. 1997. Early Devonian eurypterids with Bohemian affinities from Catalonia (NE Spain). Batalleria 7, 9-21.

Clarke, J.M. \& Ruedemann, R. 1912. The Eurypterida of New York. Vols 1-2. New York State Museum Memoir 14, 1-439.

Claypole, E.W. 1890. Carcinosoma newlini. American Geologist 6, 400 .

Cocks, L.R.M. \& TorsviK, T.H. 2002. Earth geography from 500 to 400 million years ago: a faunal and palaeomagnetic review. Journal of the Geological Society of London 159, 631-644. DOI 10.1144/0016-764901-118

Cocks, L.R.M. \& ToRsviK, T.H. 2006. European geography in a global context from the Vendian to the end of the Palaeozoic, 83-95. In Gee, D.G. \& Stephenson, R.A. (eds) European lithosphere dynamics. Geological Society of London Memoir 32.

CoPe, J.C.W. \& KŘíž, J. 2013. The Lower Palaeozoic palaeobiogeography of Bivalvia. Geological Society of London Memoirs 38, 221-241. DOI 10.1144/M38.16

Corradini, C., DelRio, M., Gnoli, M. \& Pittau, P. 2009. Minor fossil groups in the Silurian of Sardinia, 157-167. In CORRADINI, C., Ferretti, A. \& Štorch, P. (eds) The Silurian of Sardinia. Rendiconti della Società Paleontologica Italiana 3(1).

DunLOP, J.A. \& LAMSDELL, J.C. 2012. Nomenclatural notes on the eurypterid family Carcinosomatidae. Zoosystematics and Evolution 88, 19-24. DOI 10.1002/zoos.201200003

ERnst, A., MANDA, S. \& ZÁGorŠEK, K. 2011. Cryptostome bryozoan Stictoporella simplex (Počta, 1894) from the Silurian of Bohemia. Neues Jahrbuch für Geologie und Paläontologie, Abhandlungen 260, 79-85.

DOI 10.1127/0077-7749/2011/0130 
FatKa, O. \& Mergl, M. 2009. The "microcontinent" Perunica: status and story 15 years after conception, 65-101. In BASSETT, M.G. (ed.) Early Palaeozoic peri-Gondwana terranes: new insights from tectonics and biogeography. Geological Society of London Special Publication 325.

GNOLI, M. 1992. Occurrence of eurypterids (Arthropoda) in the Silurian of southwestern Sardinia. Bollettino della Società Paleontologica Italiana 31, 147-149.

GNoli, M. 2003. Northern Gondwanan Siluro-Devonian palaeogeography assessed by cephalopods. Palaeontologia Electronica 5, 1-19.

Grote, A.R. \& PitT, W.H. 1875. On new species of Eusarcus and Pterygotus from the Water Lime Group at Buffalo. Buffalo Society of Natural Science, Bulletin 3, 17-20

HavlíčEK, V. \& ŠToRCh, P. 1990. Silurian brachiopods and benthic communities in the Prague Basin (Czechoslovakia). Rozpravy Ústředního ústavu geologického 48, 1-275.

Histon, K. 2012a. An Alpine immigrant: Phragmoceras Broderip, 1839 from the Silurian of the Carnic Alps (Austria). Geobios 45, 41-48. DOI 10.1016/j.geobios.2011.11.009

Histon, K. 2012b. The Silurian nautiloid-bearing strata of the Cellon Section (Carnic Alps, Austria): color variation related to events. Palaeogeography, Palaeoclimatology, Palaeoecology 367-368, 231-255. DOI 10.1016/j.palaeo.2012.10.012

ICZN (INTERNATIONAL Commission on ZoOlogical NomenclaTURE) 1999. International Code of Zoological Nomenclature, $4^{\text {th }}$ edition. 306 pp. The International Trust for Zoological Nomenclature, London.

KJELLESVIG-WAERING, E.N. 1958. Some previously unknown morphological structures of Carcinosoma newlini (Claypole). Journal of Paleontology 32, 295-303.

KJellesvig-Waering, E.N. 1961. The Silurian Eurypterida of the Welsh Borderland. Journal of Palaeontology 35, 789-835.

Kř́ž, J. 2008. A new bivalve community from the lower Ludlow of the Prague Basin (Perunica, Bohemia). Bulletin of Geosciences 83, 237-280.

DOI 10.3140/bull.geosci.2008.03.237

Křiž, J., Degardin, J.M., Ferretti, A., Hansch, W., GuttiérezMarco, J.C., PARis, F., Piçarra D'Almeida, J.M., Robardet, M., Schönlaub, H.P. \& Serpagli, E. 2003. Silurian stratigraphy and paleogeography of Gondwanan and Perunican Europe. New York State Museum Bulletin 493, 105-178.

KŘiž, J., JAEGER, H., PARIS, F. \& SChÖNLAUB, H.P. 1986. Př́ídolí the fourth subdivision of the Silurian. Jahrbuch der Geologischen Bundesanstalt 129, 291-360.

Krs, M., Pruner, P. \& Man, O. 2001. Tectonic and paleogeographic interpretation of the paleomagnetism of Variscan and pre-Variscan formations of the Bohemian Massif, with special reference to the Barrandian terrane. Tectonophysics 332, 93-114. DOI 10.1016/S0040-1951(00)00251-1

LAMSDELL, J.C. \& BRADDY, S.J. 2010. Cope's Rule and Romer's theory: patterns of diversity and gigantism in eurypterids and Palaeozoic vertebrates. Biology Letters 6(2), 265-269. DOI 10.1098/rsbl.2009.0700

LAmsdell, J.C., HoșGÖR, I. \& Selden, P.A. 2013. A new Ordovician eurypterid (Arthropoda: Chelicerata) from southeast Turkey: evidence for a cryptic Ordovician record of Eurypterida. Gondwana Research 23, 354-366.

DOI 10.1016/j.gr.2012.04.006
Lamsdell, J.C. \& Selden, P.A. 2013. Babes in the wood - a unique window into sea scorpion ontogeny. BMC Evolutionary Biology 13 (98), 1-46.

MandA, Š. 2007. New Silurian nautiloids Phragmoceras Broderip, 1839 and Tubiferoceras Hedström, 1917 from the Prague Basin (Bohemia). Bulletin of Geosciences 82, 119-131. DOI 10.3140/bull.geosci.2007.02.119

MANDA, Š. 2008. Palaeoecology and palaeogeographic relations of the Silurian phragmoceratids (Nautiloidea, Cephalopoda) of the Prague Basin (Bohemia). Bulletin of Geosciences 83, 39-62. DOI 10.3140/bull.geosci.2008.01.039

MANDA, Š. \& FRÝDA, J. 2010. Silurian-Devonian boundary events and their influence on cephalopod evolution: evolutionary significance of cephalopod egg size during mass extinctions. Bulletin of Geosciences 85, 513-540. DOI 10.3140/bull.geosci.1174

MANDA, Š. \& Kř́iž, J. 2006. Environmental and biotic changes in subtropical isolated carbonate platforms during the late Silurian Kozlowskii Event, Prague Basin. GFF 128, 161-168. DOI 10.1080/11035890601282161

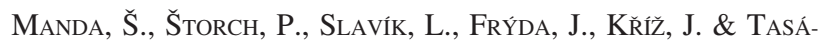
RYOVÁ, Z. 2012. The graptolite, conodont and sedimentary record through the late Ludlow Kozlowskii Event (Silurian) in the shale-dominated succession of Bohemia. Geological Magazine 149, 507-531. DOI 10.1017/S0016756811000847

Mergl, M. 2006. A review of Silurian discinoid brachiopods from historical British localities. Bulletin of Geosciences 81, 215-236. DOI 10.3140/bull.geosci.2006.04.215

Mergl, M. 2010. A review of Silurian discinoid brachiopods from Gotland, Sweden. Bulletin of Geosciences 85, 367-384. DOI 10.3140/bull.geosci.1176

Murchison, R.I. 1859. Siluria. The history of the oldest known rocks containing organic remains, with a brief sketch of the distribution of gold over the Earth. $2^{\text {nd }}$ edition. 592 pp. John Murray, London.

NovÁk, O.P. MS. Système silurien du centre de la Bohême. Part of unpublished manuscript housed in the Department of Palaeontology of the National Museum, Prague.

Perner, J. 1898. Rozhledy vědecké, geologie a paleontologie. Vesmir 30, 42-43.

PERTY, M. 1833. Delectus animalium articulorum, quae in itinere per Brasilia anni 1817-1820 peracta collegerunt J.B. Spix et de Martius. 205 pp. Friedrich Fleischer, Monachii.

PRANTL, F. \& PřibYL, A. 1948. Revise různorepých (Eurypterida) z českého siluru. Rozpravy Státního geologického ústavu Československé republiky 10, 1-116.

SCotese, C.R. \& McKerrow, W.S. 1990. Revised world maps and introduction, 1-21. In McKerrow, W.S. \& SCotese, C.R. (eds) Palaeozoic palaeogeography and biogeography. Geological Society of London Memoir 12.

SeEmann, F. 1906. Beiträge zur Gigantostrakenfauna Böhmens. Beiträge zur Paläontologie und Geologie Österreich-Ungarns und des Orients 19, 49-57.

SEMPER, M. 1898. Die Gigantostraken des älteren Böhmischen Paläozoicum. Beiträge zur Paläontologie und Geologie Österreich-Ungarns und des Orients 11, 71-88.

Stampfli, G.M., Raumer, J.F. \& Borel, G.D. 2002. Paleozoic evolution of pre-Variscan terranes: from Gondwana to the Variscan collision. Geological Society of America Special Paper 364, 263-280. 
ŠтоRCH, P. 1994. Graptolite biostratigraphy of the lower Silurian (Llandovery and Wenlock) of Bohemia. Geological Journal 29, 137-165. DOI 10.1002/gj.3350290204

ŠтоRсн, P. 1995. Upper Silurian (upper Ludlow) graptolites of the N. inexpectatus and N. kozlowskii biozones from Kosov Quarry near Beroun (Barrandian area, Bohemia). Bulletin of the Czech Geological Survey 70, 65-89.

STøRMER, L. 1934. Merostomata from the Downtonian sandstone of Ringerike, Norway. Skrifter utgitt av Det Norske Videnskaps-Akademi i Oslo. I. Matematisk-Naturvidenskapelig Klasse 10, 1-125.

Størmer, L. 1955. Merostomata, 4-41. In Moore, R.C. (ed.) Treatise on invertebrate paleontology. Part P. Arthropoda 2. Geological Society of America and University of Kansas Press, Lawrence.

STRAND, E. 1942. Miscellanea nomenclatoria zoologica et palaeontologica. X. Folia Zoologica et Hydrobiologica 11, 386-402.

TETLIE, O.E. 2004. Eurypterid phylogeny with remarks on the origin of arachnids. 320 pp. Unpublished Ph.D. dissertation, University of Bristol, UK.

TetLIE, O.E. 2007. Distribution and dispersal history of Eurypterida (Chelicerata). Palaeogeography, Palaeoclimatology, Palaeoecology 252, 557-574. DOI 10.1016/j.palaeo.2007.05.011
Tollerton, V.P. 1989. Morphology, taxonomy, and classification of the Order Eurypterida Burmeister, 1843. Journal of Paleontology 63, 642-657.

ToRsvik, T.H. \& Cocks, L.R.M. 2004. Earth geography from 400 to $250 \mathrm{Ma}$ : a palaeomagnetic, faunal and facies review. Journal of the Geological Society of London 161, 555-572. DOI 10.1144/0016-764903-098

TUREK, V. \& MANDA, Š. 2011. Colour pattern polymorphism in Silurian nautiloid Phragmoceras Broderip, 1839. Bulletin of Geosciences 86, 91-105.

DOI 10.3140/bull.geosci.1240

TureK, V. \& MANDA, Š. 2012. "An endocochleate experiment" in the Silurian straight-shelled cephalopod Sphooceras. Bulletin of Geosciences 87, 767-813.

DOI 10.3140/bull.geosci.1335

WiLDE, P., BerRy, W.B.N. \& Quinby-HunNt, M.S. 1991. Silurian oceanic and atmospheric circulation and chemistry. Special Papers in Palaeontology 44, 123-143.

Woodward, H. 1868. On some new species of Crustacea from the Upper Silurian rocks of Lanarkshire \&c; and further observations on the structure of Pterygotus. Quarterly Journal of the Geological Society of London 24, 289-296.

DOI 10.1144/GSL.JGS.1868.024.01-02.36 